\title{
Mapping of the Market Potential of Feasibility Study of the Use of Balun Gas Well, Cepu Sub-District
}

\author{
Yunanik $^{1 *}$ \\ ${ }^{1}$ Politeknik Energi dan Mineral AKAMIGAS, Cepu, Indonesia \\ *Corresponding author. Email: yunanikyuna63@gmail.com
}

\begin{abstract}
Utilization of the Balun Field Gas Well, Cepu, is related to fulfilment and improves the welfare of the Cepu people and its surroundings, then a mapping of the market potential in the area of potential gas wells in Balun Field. Utilization of the Balun Gas Well from PM 2 Balun has a gas reserve of $\pm 0.162 \mathrm{MMscf} / \mathrm{d}$, assuming the addition of gas wells is in line with the target for its use. Determination, determined by the method of using techniques that were deliberately chosen for the community in accordance with the research objectives, where the native of Balun, Cepu were sought and interviewed, then a cost-benefit analysis or commonly called a Benefit Cost Ratio. From the results of data collection and economic analysis, both technical and economic analysis, the results of the Benefit Cost Ratio (BCR) analysis obtained a B/C value of $0.9022(<1)$ indicating that economically the utilization of the Balun Field gas well project was not feasible. However, the development project of natural gas distribution pipelines is one of the efforts to contribute the development of education / as a learning tool in PEM Akamigas.
\end{abstract}

Keywords: Balun Gas Well, Feasibility Study, Benefit Cost Ratio

\section{INTRODUCTION}

The Balun Gas Field was first managed by Tobo Block, then managed by BPM until 1962 and subsequently managed by Permigan. Since PPTMGB LEMIGAS manages the Balun field, 5 drilling have been carried out; PM 1, 2, 3, 4, and 5 with an average depth of 300-500m (Selorejo Fm and Ledok). The five gas well locations are as follows: PM-1: Ngajo-Balun location, Cepu - 1968 [1], PM-2 Near PKU Muhammadiyah-Balun (Hospital's location, Cepu - 1969) [2], PM-3 Magalrejo-Balun location, Cepu - 1971 [3], PM4 Cendono - Padangan - East Java - 1972 [4], PM-5 Pusdiklat Migas Location, Cepu - 1972 [5].

The purpose of this study is to map local potentials that can be developed and analyse the needs of natural gas, especially for the household needs of Cepu and surrounding communities, industry and even Ngloram Airport when it is operational. The analysis is then carried out to determine the needs and the most efficient sequence for gas distribution, so that the gas flow plan can be carried out to integrate gas availability according to market demand.

The problem to be studied is a series of Mapping and Indepth Study of Local Potential in the Balun Gas Well Field, conducted to find out the market potential and culture of the local community or also known as social orientation activities through two stages; Estimated Market Potential and Study/ Research. The aim or objectives to be achieved of this study are:

a. General Objectives; contribute to meeting the needs of gas and improve the welfare of the community in Cepu and surrounding areas b. Specific Objectives; Assessing the feasibility of access to identification of market potential mapping, socioeconomic conditions and potentials that exist in the study area [1], Mapping/Scoping studies [2].

\section{METHOD}

Activities Type: Estimated Market Potential, Financial Feasibility Assessment and Technical Feasibility, and Business Studies. The Study and Research Area conducted by the Balun gas well field, Cepu sub - district. Data and Information Collection Techniques are carried out on a number of research objectives, including: 2 (two) urban village related to the population of Cepu sub-district, 3 (three) Government Agencies in Blora Regency, as well as, 2 (two) BUMN institutions located in Surabaya, Semarang, 5 (five) Hotels in Cepu, Small traders such as shop and stall, Hamlet/neighbourhood in the environment of Balun Village and Cepu Village. Types of Data and Information: The types of data and information needed, are netted and obtained through population, among others based on, age, gender, education level, income, occupation. Technical Data Analysis: Data processing and analysis is carried out on the data collected, to discuss Technical Feasibility and Economic Feasibility.

\section{RESULT AND DISCUSSION}

\subsection{Estimated Market Potential}

Cepu Subdistrict has an area of $246.55 \mathrm{~km}^{2}$; Cepu is divided into 17 Village. The Cepu sub-district consists of 17 hamlets and 83 neighbourhoods. Cepu sub-district is led by a district head. Balun Village is a Balun Field Gas Location 
which has an area of $481,111 \mathrm{~km}^{2}$, with a total population of 14650 people, consisting of 7237 men and 7415 women, with an average of 4 inhabitants / households with a total of 5076 households, while Cepu has an area of $246.55 \mathrm{~km}^{2}$, with a population of 17219 people, consisting of 8452 men and 8767 women, with an average of 4 inhabitants / households; with a total of 5599 families.

\subsection{Mapping Market Potential}

Mapping Market Potential in the context of the Utilization of Balun Gas Well, Cepu, by identifying the socioeconomic conditions and potentials in the study area and from the data available that the most populous hamlet are Cepu Hamlet and Balun Hamlet. Natural gas distribution to consumers through a pipeline system, and PEM Akamigas gas sales activities are fully committed to utilizing the wealth of natural gas energy resources to the entire community, including: The Natural Gas Distribution Network Area is determined by considering the source of gas based on the plan and condition of the infrastructure in the framework of gas distribution activities to consumers [1], Gas distribution determined by considering natural gas reserves and the needs of household consumers and / or small customers from various walks of life and industry, according to the allocation and utilization of natural gas for the needs of the research area [2].

\subsection{Estimate Willingness to Pay}

\subsubsection{Technical analysis}

Some important things that the expert team will do include the study of data on natural gas composition, gas flow capacity, gas pressure and temperature. It will also calculate gas flow rates for peak loads in the potential area. Technical analysis was carried out to determine the feasibility of utilizing gas from the Balun Field SR I to SR V for household gas networks in Balun and SR I to SR VI in Cepu

\subsubsection{Projection of population}

Data from the projection is done by using the geometric method, by taking the data from the 2015-2018 Civil Registry Service Office showing that the population in the Cepu Village is $20.21 \%$ per year and Balun Village 17.06 during the 2018-2028 periods, the average growth per year in the Cepu village and Balun village show a declining trend. This decrease in growth rate is determined by the decrease in birth and death rates, but the decline due to birth is faster than the decrease due to death.

\subsubsection{Price structure}

Various technical instruments have been established by the government as the legal basis for the implementation of the
$3 \mathrm{~kg}$ kerosene to LPG conversion program for households, micro businesses, and fishing vessels for small fishermen. The technical regulations that have been established are Presidential Regulation No. 104 of 2007 Provision, Distribution and Pricing of 3 Kilogram Liquefied Petroleum Gas Cylinders.

Regarding the basis for the authority to determine subsidy prices, it is stated in: ESDM Regulation No. 28 of 2008 Article 1 paragraph 1, ESDM Ministerial Regulation No. 26 of 2009 Article 24 paragraph 4. ESDM Ministerial Regulation No. 28 Article 1 paragraph 1 contains the retail sale price of $3 \mathrm{~kg}$ LPG for households and micro businesses at the agent's delivery point. Including VAT and agent margins are set at IDR12,750.--

\subsubsection{Expenditure for $L P G$}

Expenditures for the use of LPG can be calculated by multiplying LPG consumption by the price: LPG costs = LPG consumption $x$ LPG prices. The calculation is in the form of total household gas demand every month, and per year.

\subsubsection{Expenditures for natural gas}

BPH Migas sets the price of Household gas for various regions, including those that researchers use the Surabaya Gresik region, are set as follows: Household 1 IDR 2,507.-

, Household 2 IDR 3,009.- Customer 1 IDR 2,507.- , Customer 2 IDR 2,883.-

Cepu District community. Based on the calculation results, the need for natural gas in 2018 for 5076 households is $21,765,888 \operatorname{scf}(58,811 \mathrm{M} 3)$. Thus the expenditure for gas consumption in 2018 is equal to; 1) Cost $=$ IDR 147,439,177.- and 2) Cost = IDR 176,433,000.-.

\subsubsection{Benefits of LPG substitution to natural gas}

Expenditures for the use of LPG can be calculated by multiplying LPG consumption by the price: LPG costs = LPG consumption $x$ LPG prices. The calculation is in the form of total household gas demand every month, and per year. The current price of LPG for $3 \mathrm{~kg}$ cylinders is IDR 15,000 . If in one month, one household consumes 4 tubes, in one year, it will use 48 tubes.

\subsubsection{Benefit/saving cost}

Based on the calculation of LPG costs and natural gas costs above obtained savings from LPG substitution to gas in 2018 that is equal to: Saving $=$ IDR 766,488,306.- $(10.675$ KK), lowest price IDR 15,000.- per/cylinder) [1], Saving IDR $12,623,567,000 .-(10.675 \mathrm{KK}$, highest price IDR 25,000.-/cylinder, and whereas for: 5,000 KK, 240,000 Cylinder [2], 5,000 KK Saving = IDR 3,452,560,823.Saving $=$ IDR 5,823,567,000.- 


\subsubsection{Substitution savings from LPG to natural gas}

Based on the results of the projected energy needs for the next 10 years obtained saving / substitution savings from LPG to natural gas, starting in 2018 until 2028 amounting to IDR $3,452,560,823$.- to IDR $8,793,560,165$.-

\subsubsection{Saving $L P G$ to gas substitution}

In addition to the needs for households, natural gas calculations are also carried out to meet the cooking needs of food stalls in Cepu Village. The number of food stalls in the location is 10 stalls with a consumption level of 6 cylinders $(3 \mathrm{~kg})$ per month. It is assumed over a period of 10 years; the number of stalls is fixed. LPG consumption per year $=10 \times 6 \times 3 \mathrm{~kg} \times 12 \times 11.220 \mathrm{Kcal} / \mathrm{kg}=24.235 .200$ $\mathrm{Kcal}=24.235 .200 \mathrm{Kcal} \times 3,968 \mathrm{Btu} / \mathrm{Kcal}=96.165 .274 \mathrm{Btu}$. Gas consumption per year $=(96.165 .274 \mathrm{Btu}) /(1494 \mathrm{Btu}$ $/ \mathrm{Scf})=65.241 \mathrm{scf}$.

\subsection{Project Feasibility Study}

\subsubsection{Natural gas needs projection}

Therefore, the planned natural gas consumption for the Balun SR Location of 5,076 households in 2019 is 5,076 x $4,288=21,765,888 \mathrm{Scf}$ or 59,633 scf/day. Assuming losses of $5 \%$, the gas demand for 5,076 houses is $61,752 \mathrm{scf} /$ day or around $0.063 \mathrm{MMscfd}$.), while natural gas consumption for SR 10,000 households in 2019 is $10,000 \times 4,288=$ $42,880,000$ Scf or $117,479 \mathrm{Scf}$ or $117,479 \mathrm{scf} / \mathrm{day}$. Assuming a loss of $5 \%$, the gas demand for 10,000 homes is $123,353 \mathrm{scf} /$ day or around $0.123 \mathrm{MMscfd}$

\subsubsection{Investment cost}

- Scenario I. The cost of installing an assumption of 5,000 households consisting of the cost of service and construction and distribution pipelines is IDR 70,312,500.--

- Scenario II. The cost of installing an assumption of 5,000 households consisting of the costs of service and construction and distribution pipelines is IDR $50,000,000$.-

- Scenario III. The pipe installation costs above include costs for fittings, valves, and auxiliaries. Thus, the total cost for network construction with the assumption of three scenarios can be chosen and in accordance with the capacity and natural gas reserves in PM 1 and PM 2, assuming the addition of gas wells is on target for the use of household gas. And the costs incurred are the costs incurred at the beginning.

\subsubsection{Moderate (Most Realistic)}

After describing the estimated demand for natural gas that will be utilized within the next 10 years as well as alternatives / assumptions from several scenarios that have been evaluated plans to use the Balun field gas wells from PM 1 and PM2, from the simulation calculation of the development of natural gas demand PM1 and PM2 gas flow capacity nature, source capacity, and costs (CAPEX and OPEX) to carry out the three types of scenarios above, this study obtained Scenario 1, namely the cost of building a distribution pipeline as an alternative.

These additional costs include investment costs to meet the increasing number of households in Cepu and Balun villages. Distribution pipe installation, service pipes, installation pipe costs and equipment such as purchasing gas stoves for every five years is 2019 IDR 70,313,500.Year 2024 IDR 5,421,093,750.- Year 2029 IDR 542,109,375.-

\subsubsection{Cost analysis}

Cost analysis includes investment costs and operating and maintenance costs. The investment costs for the construction of a pipeline in Cepu and Balun Sub-districts have been calculated previously in the amount of IDR 14,062,000.-/households, followed by additional investments in subsequent years. In the Benefit Cost Ratio (BCR) analysis here, some of the variables to be analysed are project benefits, including the benefits or benefits of switching from using LPG to natural gas. In addition, the $\mathrm{BCR}$ variable will involve investment costs and operating and maintenance $(\mathrm{O} \& \mathrm{M})$ costs.

\subsubsection{Benefit analysis}

Benefit analysis includes the price difference from the replacement of the use of LPG to natural gas. The gas price used in this calculation is IDR 2,507.-. At the gas price, gas sales from 2018 to 2028 amounted to IDR 147,439,177.- to IDR 342,091,686.- assuming an operating and maintenance cost of $5 \%$ of gas sales and an increase of $2.5 \%$ annually.

\subsubsection{Benefit Cost Ratio $(B / C)$ analysis}

This Benefit Cost Ratio (BCR) is a comparison between Benefit and Cost where the method of determining the equivalent value can be done either by using present value analysis or future value.

In this BCR analysis it is assumed that the rate of return of capital is $6.5 \%$ per year (in accordance with the BI rate) so that the calculation results for the present value of IDR 71,619,419,759.- and PW Benefit IDR 64,614,797,204.according to the data obtained, the Benefit Cost Ratio is determined, which is IDR 64,614,797,204.-/IDR $71,619,476,759 .-=0.9022(\mathrm{~B} / \mathrm{C}<1)$ so that economically the project is not feasible to be implemented 


\subsubsection{Gas price sensitivity}

At the gas price of IDR 2,507.- / M3 obtained a B/C of less than one. One way to increase the $\mathrm{B} / \mathrm{C}$ is to reduce gas prices. In this analysis, the price of gas located in PM 2 Balun Field varied, respectively, for RT-1 (IDR/M3) were 2000, 1900, 1800, 1700, 1600, 1500, 1400, 1300, 1200, 1100,1000 and RT II (IDR/M3) is $2399,2280,2159,2695$, $1919,1800,1680,1560,1440,1320,1200$. Although the price of gas has been reduced to IDR 1,000.-/M3, but the increase in $\mathrm{B} / \mathrm{C}$ did not occur significantly.

Thus, gas prices have less influence on the increase in $\mathrm{B} / \mathrm{C}$ values, while the sensitivity of gas prices to $\mathrm{B} / \mathrm{C}$ values can be presented in Gas Prices (IDR) / BC: 2000-0.636, 19000,651,1800-0,666, 1680-0,684, 1600-0.0696, 1500-0.6696. From these data it can be seen even though the price of gas has been reduced to IDR 1,000.-/M3, but the increase in B/C did not occur significantly. Thus, the price of gas is less influential on increasing the value of $\mathrm{B} / \mathrm{C}$.

\subsubsection{Investment Cost Sensitivity}

On investment costs as shown in Table $25, \mathrm{~B} / \mathrm{C}$ is obtained less than one. One way to increase the $\mathrm{B} / \mathrm{C}$ is to reduce investment costs. In this analysis, investment costs are varied by $\pm 30 \%$. From the calculation results obtained by $\mathrm{B} / \mathrm{C}$ on each of these investment costs such as Percentage / BCR: $70 \%-0.4922,80 \%-0.33938,90 \%-03544,100 \%-$ $0.3544,110 \%-0.3898,120 \%-0.4678,130 \%-0.2756$. From the results it can be seen that the investment cost is $70 \%$ or Rp.49,218,750,00, - the $\mathrm{B} / \mathrm{C}$ value is close to 1 . Thus, the investment cost is very influential on the $\mathrm{B} / \mathrm{C}$.

\subsubsection{Discount Rate Sensitivity}

One way to increase the $\mathrm{B} / \mathrm{C}$ is to reduce the discount rate. On the basis of the above calculation, a discount rate of $6.5 \%$ is used. In this analysis, the value of the discount rate is varied to $0 \%$. From the calculation results obtained by $\mathrm{B} / \mathrm{C}$ at each of these investment costs obtained discount Rate Sensitivity to the value of B/C. Discount Rate / BCR: $6.50 \%-0.902,5 \%-0.961,4 \%-1.006,3 \%-1.042,2 \%-$ $1.078,1 \%-1.096$, and $0 \%-1.105$. From the discount rate data of $0 \% \mathrm{~B} / \mathrm{C}$ value $>1$, that is 1.105 . Thus, the amount of the discount rate affects the value of $\mathrm{B} / \mathrm{C}$ even though it is not as big as the investment cost effect.

\subsection{Optimistic}

Even though the $\mathrm{B} / \mathrm{C}$ value is below 1 (close to 1 ), this project, which is a subsidy program to the community and the source of funds originating from the Government, can still be implemented due to several considerations, giving a positive impact to the community through the use of gas wells in the field. Balun, whose benefits can be felt directly by the people who live in natural gas-producing areas, So that people feel they can get cheap and safe energy from their own area, and empower local communities to manage the operation of the gas distribution network, and are expected to be able to contribute in the development of education in PEM Akamigas.

\section{CONCLUSION}

From the results of data collection and economic analysis, both technical and economic analysis, the results of the Benefit Cost Ratio (BCR) analysis obtained a B / C value of $0.9022(<1)$ indicating that economically the project to utilize the Balun Field gas well was not feasible. The development project of natural gas distribution pipelines whose sources of funds are purely from the Government is an effort to contribute to the development of education / as a learning facility in PEM Akamigas

\section{ACKNOWLEDGMENT}

The author would like to thank PEM AKAMIGAS, who have provided support for facilities and infrastructure in this study as the agreement letter number: 30 / PEM.UPPM / 2018 dated October 8, 2018).

\section{REFERENCES}

[1] Kustanti, Sukriyah, Moerad1, dan Susilowati, Endang (2012): “Jurnal Pemetaan Potensi dan Dampak Ekonomi Masyarakat di Kawasan Pertambangan Bukit Tumpang Pitu Banyuwangi

[2] Nugroho, Hanan, "Pipa Transmisi Gas alam Kalimantan Timur - Jawa Sebagai Alternatif Untuk Memasok Kebutuhan Energi Di Jawa”, Perencana Madya Bidang Energi Di Bappenas. Ketua Tim Studi Gas Transportation Project Through Public-Private Partnership, ADB TA 4360-INO, 2005,

[3] Tinjauan Lapangan Gas Balun Sebagai Salah Satu Parameter Studi Kelayakan Pengadaan Sarana Diklat Mini LNG Plant”, Pusat Pengembangan Sumber Daya Manusia Migas (PPSDM MIGAS).

[4] Gas Alam", Indonesia Investment, Sumber: Forum Industri Pengguna Gas alam https://www.indonesiainvestments.com,

[5] Kelurahan Cepu, 2015,2016,2017,2018, Profil Kependudukan Kabupaten Blora

[6] Kementerian Energi dan Sumber Daya Mineral, Buku Jargas (jaringan gas/city gas), 2018-2027, Indonesia 
Cara Penetapan Alokasi dan Pemanfaatan serta Harga

[7] BPH Migas, Penetapan Harga Gas alam Pada Jaringan-Gas , Surat Keputusan BPH Migas, 21

Agustus 2017

[8] Peraturan Menteri Energi dan Sumber Daya Mineral Nomor 26 Tahun 2009 Tentang Penyediaan dan Pendistribusian Liquefied Petroleum Gas (Permen ESDM 26/2009)

[9] Peraturan Menteri Energi dan Sumber Daya Mineral Nomor No. 6 Tahun 2016 tentang Ketentuan dan Tata

\section{Gas Bumi.}

[10] Kebijakan Sumber dari Buku Kebijakan LPG 3 $\mathrm{Kg}$, 2016, oleh IGN Wiratmaja, Direktur Jenderal Minyak \& Gas Bumi

[11] Pemanfaatan Gas Suar Bakar Untuk Jaringan Gas Rumah Tangga” Sugiarto, Tesis, 2011. 